$>$ If you wish to post your version of this article (within these

$>$ guidelines) in your institutional repository, please include the

$>$ following wording, with 'Copyright Holder' amended as necessary (the

$>$ copyright holder is shown at the bottom of page 1 of your article):

Author Posting. (c) '2010 by Association of American Geographers', 2010.

This is the author's version of the work. It is posted here by

permission of 'Copyright Holder' for personal use, not for

redistribution. The definitive version was published in Annals of the

Association of American Geographers, , January 2010.

doi:10.1080/00045601003595537

(http://dx.doi.org/10.1080/00045601003595537)

Annals of the Association of American Geographers

Publication details, including instructions for authors and subscription information: http://www.informaworld.com/smpp/title content=t788352614

The Influence of Selective Migration Patterns Among Smokers and Nonsmokers on Geographical Inequalities in Health

Jamie R. Pearce a; Danny Dorling b

a Institute of Geography, School of GeoSciences, University of Edinburgh, s Department of

Geography,

University of Sheffield,

First published on: 18 March 2010

To cite this Article Pearce, Jamie R. and Dorling, Danny(2010) 'The Influence of Selective Migration Patterns Among

Smokers and Nonsmokers on Geographical Inequalities in Health', Annals of the Association of American Geographers,,

First published on: 18 March 2010 (iFirst)

To link to this Article: DOI: $10.1080 / 00045601003595537$

URL: http://dx.doi.org/10.1080/00045601003595537

Full terms and conditions of use:

http: / /www. informaworld. com/terms-and-conditions-ofaccess.pdf

This article may be used for research, teaching and private study purposes. Any substantial or

systematic reproduction, re-distribution, re-selling,

loan or sub-licensing, systematic supply or

distribution in any form to anyone is expressly

forbidden.

The publisher does not give any warranty express or

implied or make any representation that the contents

will be complete or accurate or up to date. The accuracy

of any instructions, formulae and drug doses

should be independently verified with primary sources.

The publisher shall not be liable for any loss,

actions, claims, proceedings, demand or costs or damages

whatsoever or howsoever caused arising directly

or indirectly in connection with or arising out of the use of this material. 


\title{
The Influence of Selective Migration Patterns Among Smokers and Nonsmokers on Geographical Inequalities in Health
}

\author{
Jamie R. Pearce* and Danny Dorling ${ }^{\dagger}$ \\ *Institute of Geography, School of GeoSciences, University of Edinburgh \\ †Department of Geography, University of Sheffield
}

\begin{abstract}
The research reported here uses New Zealand data on smoking behavior that were collected in the 1981, 1996, and 2006 national censuses. Evaluation of the extent to which differential migration patterns among smokers, former smokers, and nonsmokers contributed toward geographical inequalities in health in New Zealand suggests that the effect of selective migration appears to be significant over the long term. This effect includes the arrival of large numbers of nonsmokers from abroad to the most affluent parts of New Zealand. The recording of these events and the high quality of the census in New Zealand provides evidence of one key mechanism whereby geographical inequalities in health between areas can be greatly exacerbated across a country-differential migration by health status. This assertion has important implications for studies monitoring spatial inequalities in health over time, and research investigating "place effects" on health. Key Words: health inequalities, migration, mobility, New Zealand, smoking.
\end{abstract}

本研究所使用的数据为新西兰 1981 年, 1996 年和 2006 年全国人口普查有关吸烟行为的数据。对吸烟者, 前烟民和非吸 烟者的迁移模式差异的评估有助于分析新西兰健康状况的地域性不平衡, 研究结果表明, 选择性的移民模式产生了长期的 显著性效应。这种影响包括大批非吸烟者从国外迁移到新西兰最富庶的地区。这些被记录的事件和新西兰高品质的普查数 据为一个关键机制提供了证据, 地区之间的健康状况的地域性不平等, 可以因一个国家健康状况差异性迁徙而被大大加剧。 这种说法已经影响到一些研究, 例如监测长期的健康状况的空间不平等性, 以及研究调查健康状况的“地方影响”。关键词: 健康不平等, 迁移, 流动性, 新西兰, 吸烟。

La investigación en la que se basa este artículo utiliza datos de Nueva Zelanda sobre la conducta de fumadores, registrados en los censos nacionales de 1981, 1996 y 2006. La evaluación del grado con que los diferentes patrones de migración observados en fumadores, ex fumadores y no fumadores contribuyen a las desigualdades geográficas de la salud en Nueva Zelanda sugiere que el efecto de la migración selectiva parece ser significativa en el largo plazo. Este efecto incluye la llegada de un gran número de no fumadores desde el extranjero a las partes más opulentas del país. El registro de estos hechos, y la alta calidad del censo neozelandés, proveen evidencia de un mecanismo clave en el cual las desigualdades geográficas de salud entre diferentes áreas pueden agravarse mucho a través de un país—-migración diferencial de acuerdo con el estatus de la salud. Este aserto tiene importantes implicaciones en estudios dedicados al monitoreo de desigualdades espaciales en salud a través del tiempo, y en las investigaciones que indagan sobre "los efectos del lugar" en la salud. Palabras clave: desigualdades de salud, migración, movilidad, Nueva Zelanda, fumar.

$\mathrm{R}$ ecent studies have consistently demonstrated that in most Organisation for Economic Cooperation and Development (OECD) countries over the past twenty to thirty years, there has been a polarization in health between geographical areas (Davey Smith et al. 2002). Using various area-level measures of mortality and morbidity, researchers have tended to find that although there have been considerable improvements in health at national levels, these gains have not been consistent in all regions. In particular, there is clear evidence that less socially deprived areas have tended to benefit disproportionately from these improvements. For example, in the United States, there are extensive health inequalities among local counties, and this divide has widened considerably in recent decades (Singh and Siahpush 2006). Between 1980 and 2000 there was a 60 percent increase in the size of the gap in life expectancy between the poorest and richest tenths of the population (Dorling 2006). In New Zealand, life expectancy increased between 1981 and 
2001 from 70.4 and 76.4 years to 76.3 and 81.1 , for males and females, respectively, but these increases were not consistent for all regions of the country (Pearce and Dorling 2006), and in some (more socially deprived) places, mortality rates actually grew (Pearce et al. 2006; Pearce, Tisch, and Barnett 2008). Regional inequalities in life expectancy in New Zealand increased by approximately 50 percent over this period (Pearce and Dorling 2006), a phase of rapid social and economic change in New Zealand society (Le Heron and Pawson 1996).

There has been considerable attention given to unraveling the processes that establish and perpetuate geographical inequalities in health, and include explanations relating to the characteristics of the people living in the areas (e.g., age, sex, socioeconomic status, and ethnicity) but also features of the places themselves (e.g., local resources and health services, area deprivation, and environmental disamenities such as air pollution). One potential driver of spatial inequalities in health is the process of health selective migration (Anderson, Ferris, and Zickmantel 1964; Kelsey, Mood, and Acheson 1968; Bentham 1988). Research into health selective migration has considered whether "healthy" or "unhealthy" people have a greater or lesser propensity to move residence, as well as the implications of such movements for changing patterns in area-level health inequalities. If a sorting process occurs in which people in better health are more likely to move to (or remain in) less deprived areas, and those in poorer health are more likely to move into (or remain in) more deprived areas, then spatial inequalities in health will be exacerbated. Although the potential significance of selective migration effects for geographical studies has long been recognized (Anderson, Ferris, and Zickmantel 1964; Fox and Goldblatt 1982), only recently have researchers attempted to quantify the effects of these processes on spatial inequalities in health. The health inequalities literature has not tended to examine selective mobility proactively as a partial account for the geographical patterning in health status and health-related behaviors. At best, health-related migration and mobility has been considered as a statistical artifact rather than a substantive area of academic enquiry (Smith and Easterlow 2005).

Research in Great Britain has tended to demonstrate that selective migration and immobility has strengthened the relationship between area deprivation and various health outcomes including mortality (Brimblecombe, Dorling, and Shaw 1999; Norman, Boyle, and Rees 2005; Connolly, O'Reilly, and Rosato 2007), Type
2 diabetes (Cox et al. 2007), and ischemic heart disease (Strachan, Leon, and Dodgeon 1995). For example, an examination of 10,264 British residents enumerated as part of the British Household Panel Survey in 1991 found that at the local (district) scale the major geographical variations in age- and sex-standardized mortality could be attributed to selective migration (Brimblecombe, Dorling, and Shaw 1999). This effect was particularly pronounced among men. Similarly, using longitudinal data in England and Wales over a twenty-year period (1971-1991), Norman, Boyle, and Rees (2005) found that the migrants who move from more to less deprived areas are significantly healthier than migrants who move from less to more deprived areas, and that the largest absolute flow was by relatively healthy migrants moving away from more deprived areas toward less deprived areas.

The results from studies of selective migration effects outside of Great Britain are more mixed. The findings of research in Australia (Larson, Bell, and Young 2004) and the United States (Landale, Gorman, and Oropesa 2006) concur with the British work and suggest that differential migration patterns between healthy and unhealthy groups are a key explanation in understanding the varying health outcomes in the providing and receiving areas. On the other hand, research in The Netherlands, Northern Ireland, and Norway demonstrates that selective migration patterns have had little, if any, effect on neighborhood (Dalgard and Tambs 1997; Connolly and O'Reilly 2007; van Lenthe, Martikainen, and Mackenbach 2007), or urban-rural (Verheij et al. 1998) inequalities in health. For example, van Lenthe, Martikainen, and Mackenbach (2007) studied individuals aged twenty-five to seventy-four living in the city of Eindhoven in The Netherlands and found that after adjustment for sociodemographic characteristics at the individual level, selective migration made a negligible contribution to neighborhood inequalities in health and health-related behaviors within the city; however, although 27,070 people were targeted to participate in this study, 30 percent of those approached refused to participate, and a further 45 percent of respondents were excluded because they did not reside within the city limits. The exclusion of this group seems surprising given that it has been established that the migration patterns between urban and rural areas tend to be selective. Further, respondents younger than twenty-five, and those who moved but whose location was unknown, were also excluded. Therefore, the study design might have minimized any measurable effects of selective migration patterns. A study in 
Northern Ireland for the period 2000 to 2005 found that although there was evidence of significant variations in health between migrants and nonmigrants, this differential had no impact on neighborhood inequalities in health, partly because migrants out of deprived areas had a similar health status to the replacement inmigrants (Connolly and O'Reilly 2007); however, the study period was a particularly unusual period of change in the recent history of Northern Ireland. Other than the former Yugoslavia and Cyprus, there are few other European examples where residential migration has been more disrupted by violence in the last three decades. Until recently, few people from affluent areas of the United Kingdom would consider moving even to prosperous areas of Northern Ireland and outmigration flows were high from many parts of Northern Ireland, not simply the poorest places (Dorling and Thomas 2004). The unusual circumstances in Northern Ireland might have hindered the general patterns of differential migration that are evident in most OECD countries.

With a few exceptions, the majority of the evidence from the international literature suggests that selective migration patterns are significant in furthering our understanding of spatial inequalities in health. Although there is a growing literature that has evaluated the selective migration patterns of "healthy" and "unhealthy" groups, as well as considering the implication of these processes for health inequalities, most researchers have relied on measures such as mortality and self-reported health status. Few studies have evaluated the mobility patterns of individuals characterized by various health-related behaviors such as smoking. This omission is perhaps surprising given that smoking is on the causal pathway between socioeconomic status and poor health. Smoking is also one of the most important public health issues worldwide and is a major determinant of preventable mortality and morbidity in developed and developing countries (U.S. Office of the Surgeon General 2004).

In New Zealand, the consumption of tobacco has been estimated to be responsible for hastening approximately 15 percent of all deaths (New Zealand Ministry of Health 2003), with higher rates of consumption, and therefore smoking-related mortality, among lower socioeconomic groups (Blakely and Wilson 2005). It has been estimated that the contribution of tobacco smoking to inequalities in mortality increased between 1984 and 1999 from 16 to 21 percent for males, and 3 to 11 percent for females (Blakely and Wilson 2005). In addition, previous New Zealand research into smoking behavior has demonstrated that various characteristics of places including social deprivation (Moon and Barnett 2003; Pearce et al. 2009), segregation (Barnett 2000), and social inequality (Barnett, Moon, and Kearns 2004; Barnett, Pearce, and Moon 2005) exert an independent influence on smoking behavior.

In this New Zealand study we use data on smoking behavior that were collected as part of three national censuses over twenty-five years (1981, 1996, and 2006) to evaluate the implications of selective migration patterns on spatial inequalities in health. We consider whether there is a selective movement of smokers and nonsmokers between regions of high and low levels of social deprivation during the period from 1976 to 2006. There has been no previous research into the effect of selective migration patterns on spatial inequalities in health in New Zealand, which is perhaps surprising given that it is a country with particularly high levels of internal and external migration. The percentage of New Zealand residents who were born overseas has increased from 17.5 percent in 1996 to 22.9 percent in 2006 (Statistics New Zealand 2007c), which is one of highest proportions among OECD countries (OECD 2008). In recent years, immigration policy in New Zealand has shifted from a focus on absolute targets for immigration to a strategy concerned with settlement outcomes, particularly with regard to the skills mix of long-term migrants (Spoonley and Bedford 2008). The greater emphasis on attracting highly skilled migrants to New Zealand is likely to have led to an increasingly selective (and potentially healthier) migrant stream (Bedford 2004). For example, since the start of the twenty-first century, there has been a marked rise in the number of immigrant workers in specialist professions such as medicine (Connell 2007; North 2007). Migrants into New Zealand are markedly younger and underrepresented in low-income groups compared to the entire New Zealand population (Statistics New Zealand 2007d). Historically, the largest migration streams into New Zealand have been from the United Kingdom and Ireland. Although these two countries remain the largest source of migrants into the country, the magnitude of these movements has declined in both relative and absolute terms. In 2001, approximately one third (32.2 percent) of overseas-born New Zealand residents originated from the United Kingdom and Ireland, but by 2006 this proportion had fallen to 28.6 percent. Conversely, the proportion of overseasborn New Zealanders originating from Asian countries had increased from 23.7 percent to 28.6 percent over the same time period (Statistics New Zealand 2007a). 
Recent migrants are not evenly dispersed across the country, with over 75 percent of those arriving in New Zealand residing in the three largest urban centers (Auckland, Wellington, and Christchurch; New Zealand Department of Labour 2003). Between 2001 and 2006, 14.4 percent of the Auckland population moved into the region from overseas - the highest proportion of any region in the country (Statistics New Zealand 2007a). More than a third (37 percent) of people living in the Auckland region in 2006 were born overseas, compared to only 7.6 percent in the Southland region (the region with the lowest figure). New Zealanders are also becoming increasingly mobile, with 58 percent of the total population changing their usual residence at least once in the five years prior to the 2006 census and 25 percent moving within the previous twelve months. These figures compare to 55 percent and 24 percent, respectively, in 2001. In 2006, only 10 percent of the population had remained at their usual residence for twenty years (Statistics New Zealand 2007b). These high levels of immigration and internal mobility invariably lead to high levels of population sorting between areas. Further, New Zealand exhibits high levels of emigration, with an estimated 17 percent of the population born in New Zealand now living overseas (Worldmapper 2008). Therefore, New Zealand is an important setting for evaluating the effects of selective migration on health inequalities.

\section{Data and Methods}

\section{Smoking Data}

The New Zealand Censuses of 1981, 1996, and 2006 recorded the cigarette smoking status of all people aged fifteen and over. The smoking status of each respondent was defined using the responses to two questions:

1. Do you smoke cigarettes regularly (that is, one or more a day)?

2. Have you ever been a regular smoker of one or more cigarettes a day?

Each respondent was classified as being a smoker, exsmoker, or having never smoked. The 1981, 1996, and 2006 smoking data were obtained for males and females, for ten-year age groups (from fifteen to twenty-four up to eighty-five and older), and for each of the twentyone district health boards (DHBs) across New Zealand (Figure 1). DHBs have an average population size of 194,000 , ranging from 31,000 to 489,000 people (New

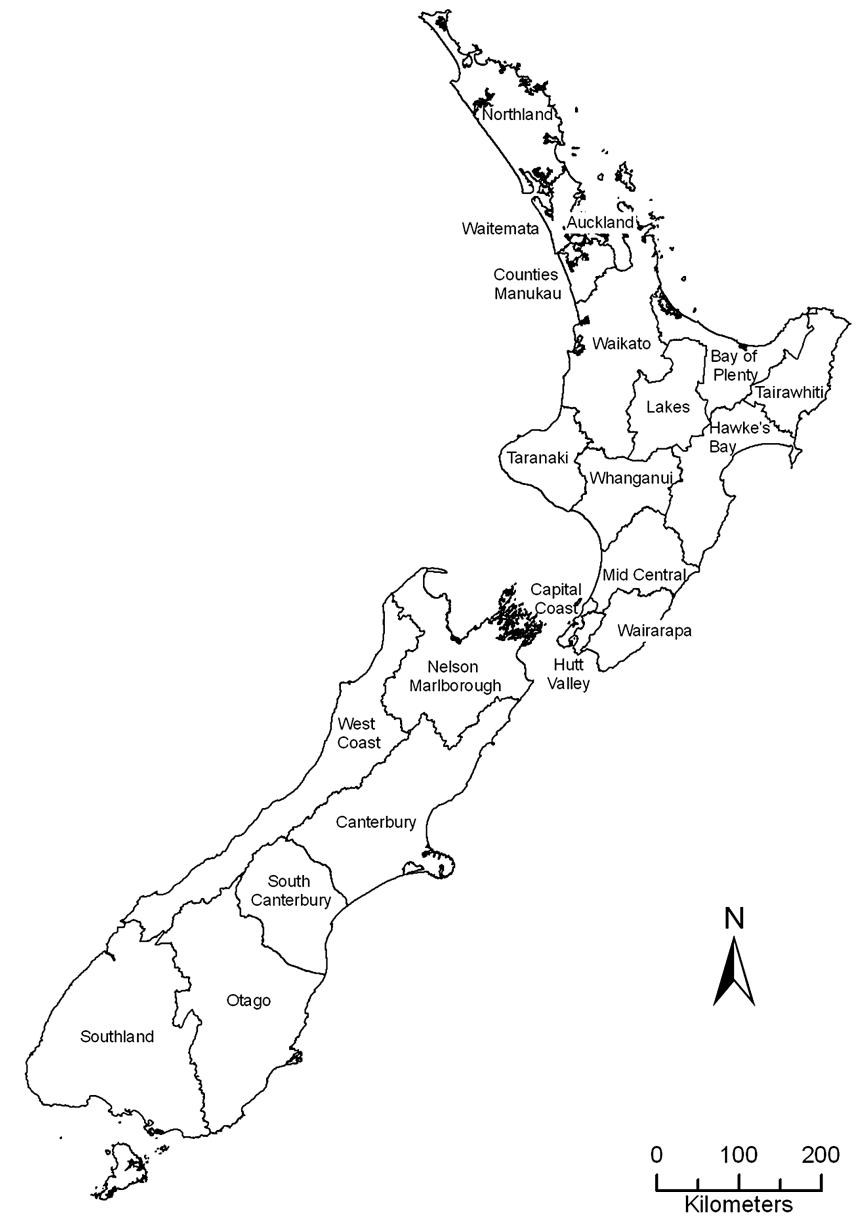

Figure 1. District health boards across New Zealand (2006).

Zealand Ministry of Health 2005), and vary significantly in terms of socioeconomic characteristics and health outcomes (Table 1). These geographical units were selected as the scale of analysis because of the substantial disparities in both health status and social deprivation across DHBs, as well as the dynamic relationship between these two factors over time (Pearce and Dorling 2006; Pearce et al. 2006). The DHBs were formed in 2001 and are responsible for the provision of health and disability services in the region. Although DHBs did not exist as administrative units throughout the period of study, they were formed from long-standing administrative units based around major hospitals that were responsible for the provision of secondary and tertiary health services in their geographical districts. The boards' catchment areas are aggregations of census area units (CAUs), which are the second smallest unit for the dissemination of census data in New Zealand, and hence census information can be extracted for populations living within DHB boundaries. The smoking data 
Table 1. Demographic and socioeconomic characteristics of the twenty-one district health boards across New Zealand

\begin{tabular}{|c|c|c|c|c|c|c|c|c|c|}
\hline \multirow{2}{*}{$\begin{array}{l}\text { District health } \\
\text { board }\end{array}$} & \multicolumn{3}{|c|}{ Population count (over 15) } & \multicolumn{4}{|c|}{$\%$ residents in deprivation deciles $8-10^{\mathrm{b}}$} & \multicolumn{2}{|c|}{$\begin{array}{l}\text { Life expectancy } \\
\quad(2001)\end{array}$} \\
\hline & Total population & Total males & Total females & Decile 8 & Decile 9 & Decile 10 & Deciles 8-10 & Males & Females \\
\hline Northland & 113,661 & 55,083 & 58,581 & 12.4 & 14.2 & 21.9 & 48.5 & 74.8 & 79.0 \\
\hline Waitemata & 377,061 & 180,906 & 196,155 & 8.4 & 6.1 & 2.3 & 16.8 & 78.0 & 81.8 \\
\hline Auckland & 328,527 & 158,004 & 170,523 & 9.9 & 9.4 & 11.0 & 30.3 & 77.0 & 82.1 \\
\hline Counties Manukau & 320,973 & 153,732 & 167,241 & 9.0 & 14.2 & 21.2 & 44.4 & 75.4 & 80.7 \\
\hline Waikato & 261,828 & 126,513 & 135,318 & 11.1 & 12.7 & 11.7 & 35.5 & 75.5 & 80.8 \\
\hline Lakes & 74,457 & 35,829 & 38,631 & 11.6 & 14.8 & 17.3 & 43.7 & 72.8 & 77.9 \\
\hline Bay of Plenty & 151,317 & 72,234 & 79,086 & 10.2 & 13.5 & 13.5 & 37.2 & 74.3 & 81.1 \\
\hline Tairawhiti & 32,811 & 15,699 & 17,112 & 11.6 & 17.4 & 30.1 & 59.1 & 73.4 & 78.5 \\
\hline Taranaki & 81,564 & 39,525 & 42,042 & 11.8 & 10.2 & 7.6 & 29.6 & 75.7 & 81.1 \\
\hline Hawke's Bay & 114,153 & 54,612 & 59,544 & 10.6 & 11.3 & 15.7 & 37.6 & 74.8 & 79.5 \\
\hline Whanganui & 48,411 & 23,328 & 25,086 & 12.0 & 14.4 & 17.3 & 43.7 & 73.4 & 78.3 \\
\hline MidCentral & 124,917 & 59,787 & 65,127 & 12.5 & 12.3 & 7.4 & 32.2 & 75.1 & 79.8 \\
\hline Hutt Valley & 105,261 & 50,943 & 54,318 & 8.1 & 9.0 & 9.9 & 27.0 & 76.2 & 80.2 \\
\hline Capital and Coast & 214,743 & 102,141 & 112,602 & 6.0 & 4.5 & 9.1 & 19.6 & 77.3 & 81.5 \\
\hline Wairarapa & 30,462 & 14,688 & 15,774 & 10.1 & 9.9 & 4.8 & 24.8 & 73.5 & 80.6 \\
\hline $\begin{array}{l}\text { Nelson } \\
\text { Marlborough }\end{array}$ & 104,292 & 50,865 & 53,427 & 10.2 & 6.4 & 1.1 & 17.7 & 76.6 & 81.3 \\
\hline West Coast & 24,930 & 12,594 & 12,336 & 20.0 & 11.0 & 6.3 & 37.3 & 74.1 & 80.1 \\
\hline Canterbury & 374,715 & 180,801 & 193,917 & 9.1 & 6.9 & 3.4 & 19.4 & 76.8 & 81.9 \\
\hline South Canterbury & 43,374 & 20,985 & 22,389 & 10.7 & 7.0 & 1.9 & 19.6 & 74.5 & 80.6 \\
\hline Otago & 147,483 & 70,968 & 76,518 & 9.5 & 9.5 & 4.0 & 23.0 & 75.5 & 81.1 \\
\hline Southland & 85,011 & 42,078 & 42,933 & 9.2 & 8.7 & 3.6 & 21.5 & 74.4 & 79.3 \\
\hline
\end{tabular}

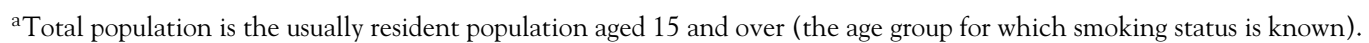

${ }^{\mathrm{b}}$ The deprivation figures show the percentage of the resident population in each district health board who were among the most deprived 30 percent of New Zealanders. Deprivation is measured using the 2001 New Zealand Deprivation Index.

were in turn cross-tabulated by DHB of origin (or from outside the country) five years earlier for those that had migrated $(n$ in $1981=2,296,704 ; 1996=2,786,220$; $2006=3,160,371$ people).

\section{Migration Effects}

Demographic accounting was undertaken to first ascertain the net movement of smokers into each area due to internal migration within New Zealand. To determine the overall migration balance it was necessary to examine the movement of both smokers and nonsmokers into and out of each DHB. The methodology is best described by using an example (see Figure 2 for an outline of the methods). If more male smokers came to Auckland than left Auckland, then all else being equal, we would expect males living in Auckland to report worse health over time. In 1981, there were 108,711 males (aged fifteen and older) living in the Auckland DHB. Of these, 36,651 were smokers, and of this total 10,431 were living outside of Auckland five years previously (and of these migrant smokers, 3,264 had migrated into New Zealand during that period). Therefore, in 1981 just over one third of the males in the Auckland DHB were smokers; a third of male smokers had arrived in the Auckland DHB within the previous five years; and of this group of migrant male smokers, one third were new (past five years) arrivals into New Zealand. In addition, it is possible to calculate that a further 34,584 male smokers who had lived in Auckland in 1976 were living elsewhere in New Zealand by 1981. However, we cannot ascertain how many had left Auckland to live overseas, as these data are not collected. Therefore, ignoring emigrants, there were 2,067 $(36,651-34,584)$ more smokers in Auckland in 1981 than in 1976.

Although there were more male smokers in Auckland in 1981 than in 1976, it does not necessarily follow that a higher proportion of males in the Auckland DHB were smokers in 1981 than 1976 because the overall population of the city grew over this period (and people who do not move might alter their smoking behavior). To determine whether the overall migration balance of smokers and nonsmokers was positive or negative 


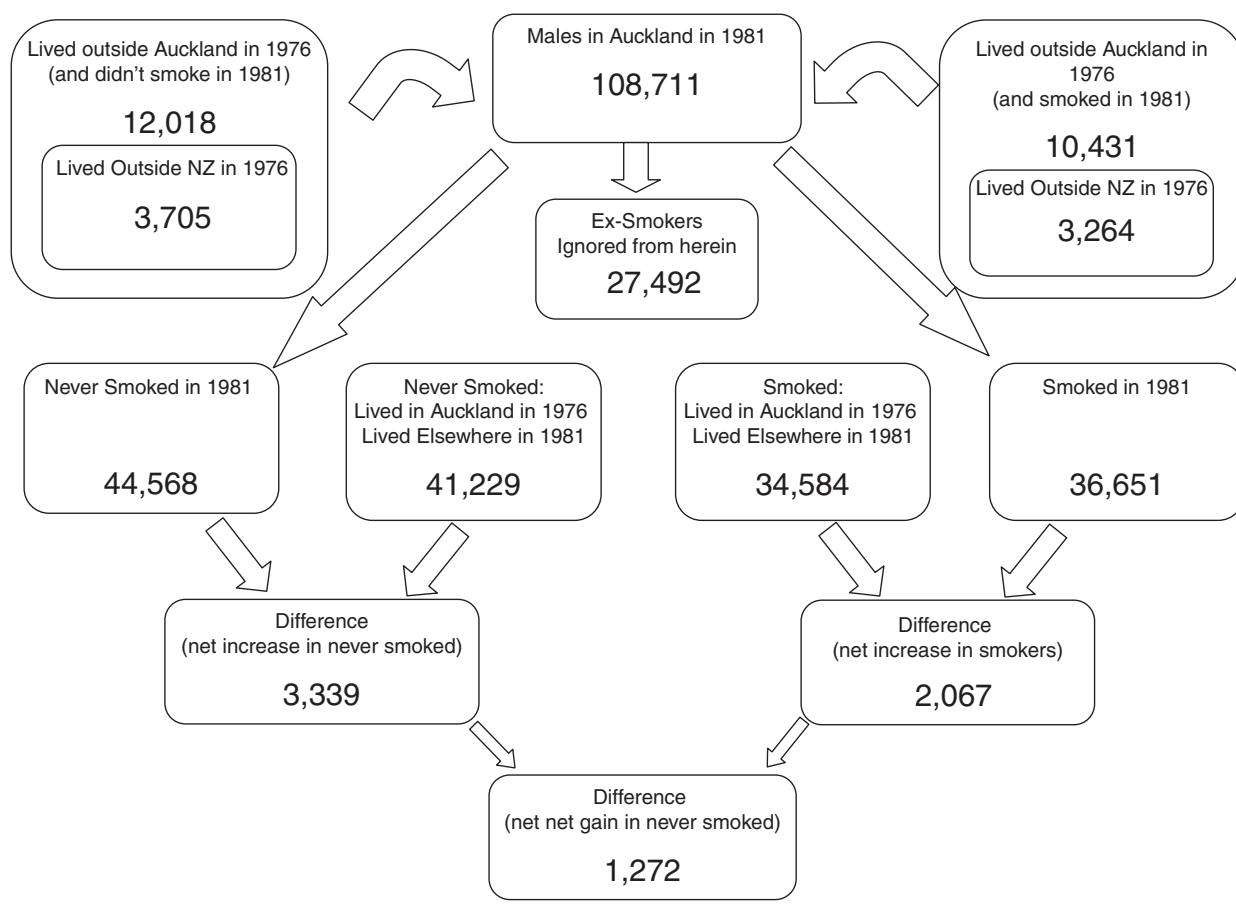

Figure 2. Flowchart depicting the methods used to calculate the smoking migration balance in the Auckland district health board (1981).

we must also consider the movements of those who have never smoked. From the 1981 census we can calculate that of the 108,711 males living in the Auckland DHB, 44,568 never smoked, and of those some 12,018 had been living outside of Auckland DHB five years previously (and of these 3,705 migrated to New Zealand during this period). Therefore, in 198141 percent of males in Auckland had never smoked, of whom 27 percent had moved into the city, in turn of whom, 31 percent had arrived into the country. Some 41,229 men who had never smoked and lived in Auckland in 1976 now lived elsewhere. So the balance of never-smokers to Auckland by 1981 was 3,339 (44,568 - 41,229). Again we have to ignore emigrants.

If we consider the overall change in the balance of smokers that can be attributed to selective migration patterns during the period from 1976 to 1981 in the Auckland DHB, then we find that there was a net gain of 2,067 smokers and 3,339 never-smokers, which resulted in a 1,272 net gain in never-smokers in 1981 compared to 1976 . This figure represents 1.2 percent of the male population of the Auckland DHB. These calculations were completed for males and females in all DHBs across the country for each time period for which smoking data were collected (1981, 1996, and 2006). To investigate the potentially different influences of internal and international migration on the smoking balance, the analyses were repeated with immigrants excluded from the calculations.

\section{Effects on Life Expectancy}

To provide an indication of whether selective migration patterns might be significant in explaining spatial inequalities in health in New Zealand, an estimate of the effect on life expectancy was calculated. Male and female life expectancies in 2001 were computed for each of the DHBs (see Pearce and Dorling 2006 for details). The difference in life expectancy between smokers and never-smokers can be estimated as seven years (Shaw, Mitchell, and Dorling 2000). Therefore, in the Auckland DHB an additional 1.2 percent of the male population not smoking over the five-year period is a benefit over a seventy-five-year lifetime equates to approximately 1.26 years of life $(7 * 0.012 *(75 / 5))$, or an extra 460 days. Of course, this calculation requires a number of assumptions to be made, including that we are considering all current smokers to consume a similar quantity of tobacco and that there is no differential bias in nonresponse to these questions on the census form. Even given these limitations, however, the least we would expect is that places with negative smoker net-net migration balances do better than places receiving more smokers (net). The net-net balance is the change in the net balance due to migration over time that was described earlier for the Auckland DHB (see Figure 2).

In these analyses, we exclude ex-smokers because their effect can be assumed to be approximately neutral, 
neither increasing nor decreasing the overall rate of smoking in an area. On average, a smoker loses four years of life expectancy, a never-smoker gains three years, and for ex-smokers the mean effect is approximately zero depending on the levels of tobacco consumption and the duration of their smoking careers (Shaw, Mitchell, and Dorling 2000). Therefore, the vast majority of the geographical variability in mortality that is attributable to the differential patterns of mobility between smokers and nonsmokers can be explained by considering only the movements of current smokers and those who have never smoked.

\section{Results}

\section{Trends in Smoking Rates: 1981 to 2006}

Between 1981 and 2006, overall smoking rates in New Zealand fell from 34 percent for males and 29 percent for females to 20 percent for males and 18 percent for females, a reduction of 41 percent and 38 percent, respectively (Table 2 ). Although there has been a decrease in smoking rates in all DHBs across the country for both males and females, the reduction has not been consistent in all regions. For males, the drop in smoking rates ranged from 31 percent in the West Coast DHB to 49 percent in the Capital and Coast DHB (containing the city of Wellington). Smoking rate reductions for women ranged from 29 percent in the Tairawhiti DHB to 57 percent in the Auckland DHB.

The correlation between the rate of smoking by area in 1981 and the ratio of smoking in 2006 to 1981 was 0.34 for men and 0.25 for women. Therefore, the higher the rate of smoking in an area in 1981, the higher the ratio of smoking in 2006 compared to 1981. This finding suggests that the DHBs with the highest smoking rates in 1981 also tend to be areas with the lowest reduction in smoking rates (as a proportion) between 1981 and 2006. Similarly, for males the gap between the areas of highest and lowest smoking increased from 7.5 percent in 1981 to 8.5 percent by 2006 . For females, the gap increased from 12.5 percent to 15.1 percent over the same time period. Therefore, although there is clear evidence of widening inequalities in arealevel smoking prevalence in New Zealand, the extent to which these trends are driven by the selective migration patterns of smokers and nonsmokers within and into New Zealand is not apparent from this simple table.

Table 2. Male and female smoking rates (crude) in New Zealand by district health board in 1981, 1996, and 2006

\begin{tabular}{|c|c|c|c|c|c|c|c|c|}
\hline & Males 1981 & Females 1981 & Males 1996 & Females 1996 & Males 2006 & Females 2006 & $\begin{array}{c}\text { Ratio males } \\
\text { 2006:1981 }\end{array}$ & $\begin{array}{c}\text { Ratio females } \\
\text { 2006:1981 }\end{array}$ \\
\hline Northland & 34.70 & 30.66 & 25.10 & 25.09 & 22.65 & 22.80 & 0.65 & 0.74 \\
\hline Waitemata & 31.65 & 27.31 & 20.71 & 18.40 & 17.67 & 14.39 & 0.56 & 0.53 \\
\hline Auckland & 33.71 & 28.40 & 20.49 & 16.78 & 17.55 & 12.30 & 0.52 & 0.43 \\
\hline Counties Manukau & 34.78 & 30.26 & 24.03 & 21.76 & 21.51 & 18.25 & 0.62 & 0.60 \\
\hline Waikato & 34.62 & 29.48 & 23.59 & 22.67 & 21.14 & 20.19 & 0.61 & 0.68 \\
\hline Lakes & 39.21 & 37.14 & 26.97 & 28.53 & 23.73 & 25.26 & 0.61 & 0.68 \\
\hline Bay of Plenty & 33.80 & 30.19 & 23.66 & 23.34 & 20.35 & 20.46 & 0.60 & 0.68 \\
\hline Tairawhiti & 37.50 & 33.96 & 27.16 & 27.69 & 25.64 & 27.44 & 0.68 & 0.81 \\
\hline Taranaki & 34.34 & 28.44 & 23.42 & 22.14 & 20.71 & 20.02 & 0.60 & 0.70 \\
\hline Hawke's Bay & 36.41 & 31.42 & 25.16 & 24.49 & 22.81 & 22.63 & 0.63 & 0.72 \\
\hline Whanganui & 36.95 & 31.10 & 26.01 & 24.99 & 24.13 & 23.64 & 0.65 & 0.76 \\
\hline MidCentral & 32.99 & 27.66 & 22.60 & 21.83 & 21.57 & 20.62 & 0.65 & 0.75 \\
\hline Hutt Valley & 35.74 & 31.68 & 23.98 & 22.95 & 21.77 & 21.08 & 0.61 & 0.67 \\
\hline Capital and Coast & 33.47 & 29.74 & 20.67 & 19.13 & 17.14 & 14.98 & 0.51 & 0.50 \\
\hline Wairarapa & 36.99 & 31.28 & 27.00 & 25.31 & 22.18 & 21.36 & 0.60 & 0.68 \\
\hline Nelson Marlborough & 31.40 & 24.61 & 21.98 & 19.14 & 19.25 & 16.53 & 0.61 & 0.67 \\
\hline West Coast & 34.47 & 29.38 & 25.53 & 24.45 & 23.65 & 23.08 & 0.69 & 0.79 \\
\hline Canterbury & 31.39 & 25.62 & 21.24 & 18.87 & 18.78 & 16.22 & 0.60 & 0.63 \\
\hline South Canterbury & 32.92 & 25.67 & 22.32 & 20.48 & 20.53 & 19.03 & 0.62 & 0.74 \\
\hline Otago & 34.40 & 28.03 & 22.50 & 19.92 & 19.21 & 16.88 & 0.56 & 0.60 \\
\hline Southland & 36.07 & 29.70 & 25.29 & 23.77 & 22.52 & 21.08 & 0.62 & 0.71 \\
\hline Total & 33.97 & 28.91 & 22.77 & 21.02 & 20.01 & 17.90 & 0.59 & 0.62 \\
\hline
\end{tabular}




\section{Smoking Migration Balance}

The widening geographical gap in smoking behavior across DHBs in New Zealand between 1981 and 2006 is only partly attributable to unequal smoking cessation rates between areas. In addition, an important component of this widening gap is the differential migration patterns between regions according to their smoking status (and no doubt many other social characteristics). Earlier we showed how demographic accounting can be used to estimate the proportion of change that is attributable to migration patterns (Figure 2). Table 3 shows the effects of such accounting for all DHBs. The net balance ranged from a 2.2 percent gain in never smokers in Capital and Coast, to a 1.5 percent gain in smokers in Wairarapa and in Whanganui (compared to the already mentioned 1.2 percent net increase in never smokers in the Auckland DHB). Capital and Coast are among the DHBs with the lowest levels of social deprivation in New Zealand, whereas Wairarapa and Whanganui report considerably higher rates of poverty (see Table 1).

Table 3. The smoking migration balance of men, total, excluding immigrants, absolute and relative difference, by district health board, 1976-1981

\begin{tabular}{|c|c|c|c|c|}
\hline $\begin{array}{l}\text { District health } \\
\text { board }\end{array}$ & $\begin{array}{c}1981 \\
\text { balance } \\
(\%)\end{array}$ & $\begin{array}{c}\text { No } \\
\text { immigrants } \\
(\%)\end{array}$ & $\begin{array}{c}\text { Difference } \\
(\%)\end{array}$ & $\begin{array}{c}\text { Difference a } \\
\% \text { of origina } \\
\text { balance }\end{array}$ \\
\hline Northland & 1.2 & 1.1 & 0.1 & 5 \\
\hline Waitemata & -0.9 & -0.6 & -0.3 & 32 \\
\hline Auckland & -1.2 & -0.8 & -0.4 & 37 \\
\hline $\begin{array}{l}\text { Counties } \\
\text { Manukau }\end{array}$ & -0.7 & -0.4 & -0.3 & 38 \\
\hline Waikato & 0.0 & 0.1 & -0.1 & \\
\hline Lakes & 0.4 & 0.2 & 0.2 & 50 \\
\hline Bay of Plenty & -1.2 & -1.1 & -0.1 & 11 \\
\hline Tairawhiti & 1.4 & 1.2 & 0.2 & 11 \\
\hline Taranaki & 0.5 & 0.7 & -0.2 & 46 \\
\hline Hawke's Bay & 0.7 & 0.4 & 0.3 & 36 \\
\hline Whanganui & 1.5 & 1.3 & 0.2 & 16 \\
\hline MidCentral & -0.1 & 0.2 & -0.3 & 310 \\
\hline Hutt Valley & 0.7 & 0.9 & -0.2 & 26 \\
\hline $\begin{array}{l}\text { Capital and } \\
\text { Coast }\end{array}$ & -2.2 & -1.6 & -0.6 & 29 \\
\hline Wairarapa & 1.5 & 1.4 & 0.1 & 9 \\
\hline $\begin{array}{l}\text { Nelson } \\
\quad \text { Marlborough }\end{array}$ & 0.2 & 0.3 & -0.1 & 38 \\
\hline West Coast & 1.2 & 0.9 & 0.3 & 24 \\
\hline Canterbury & 0.0 & 0.3 & -0.3 & \\
\hline $\begin{array}{l}\text { South } \\
\text { Canterbury }\end{array}$ & 1.3 & 1.0 & 0.3 & 25 \\
\hline Otago & 0.1 & 0.3 & -0.2 & 206 \\
\hline Southland & 0.9 & 0.8 & 0.1 & 14 \\
\hline
\end{tabular}

\section{Effects of International Migration}

To examine the influence of international migration, the analysis was repeated with immigrants excluded. Table 3 provides an illustration of how the smoking balance was calculated for the period from 1976 to 1981 (the results for the other years and for females are reported in Table 4 later). Column two of Table 3 shows the male smoking migration balances (1976-1981) for all males (including immigrants) for each DHB across the country. Excluding immigrants from the analysis had a significant effect. The third column in Table 3 shows the smoking balance excluding the effect of those who migrated to New Zealand from abroad. The fourth column shows how large the difference between these values was as a proportion of the total population, and the final column shows this value as a proportion of the original balance. Again using the Auckland DHB as an example, if immigrants are excluded from the analysis then this DHB's net smoking migration advantage falls from 1.2 percent (as outlined earlier) to 0.80 percent. A third of Auckland's advantage is due to the selective migration of its immigrants $(1.20-0.80=0.40$, which is one third of 1.2). Auckland attracts a greater proportion of nonsmoking immigrants from outside of

Table 4. The smoking migration balance of men and women combined, excluding immigrants, by district health board: 1976-1981, 1991-1996, and 2001-2006, and standard deviation

\begin{tabular}{lrrr}
\hline District health board & 1981 & 1996 & 2006 \\
\hline Northland & $1.2 \%$ & $1.3 \%$ & $1.7 \%$ \\
Waitemata & $1.0 \%$ & $1.4 \%$ & $1.3 \%$ \\
Auckland & $0.8 \%$ & $1.4 \%$ & $0.8 \%$ \\
Counties Manukau & $0.1 \%$ & $0.3 \%$ & $0.3 \%$ \\
Waikato & $1.1 \%$ & $1.9 \%$ & $2.1 \%$ \\
Lakes & $1.2 \%$ & $1.4 \%$ & $1.3 \%$ \\
Bay of Plenty & $-1.1 \%$ & $-0.6 \%$ & $-0.3 \%$ \\
Tairawhiti & $1.3 \%$ & $0.8 \%$ & $0.5 \%$ \\
Taranaki & $-0.2 \%$ & $0.1 \%$ & $0.2 \%$ \\
Hawke's Bay & $0.0 \%$ & $0.5 \%$ & $1.1 \%$ \\
Whanganui & $0.9 \%$ & $0.7 \%$ & $1.2 \%$ \\
MidCentral & $0.7 \%$ & $1.6 \%$ & $2.0 \%$ \\
Hutt Valley & $-1.7 \%$ & $-0.8 \%$ & $-1.0 \%$ \\
Capital and Coast & $-0.9 \%$ & $-0.1 \%$ & $0.1 \%$ \\
Wairarapa & $0.3 \%$ & $-0.5 \%$ & $-0.7 \%$ \\
Nelson Marlborough & $0.4 \%$ & $1.1 \%$ & $0.6 \%$ \\
West Coast & $0.4 \%$ & $-0.6 \%$ & $-2.4 \%$ \\
Canterbury & $0.0 \%$ & $-0.8 \%$ & $0.5 \%$ \\
South Canterbury & $0.9 \%$ & $1.5 \%$ & $0.8 \%$ \\
Otago & $0.1 \%$ & $0.1 \%$ & $0.8 \%$ \\
Southland & $-0.9 \%$ & $-1.1 \%$ & $-1.5 \%$ \\
Standard deviation & 0.008 & 0.009 & 0.011 \\
\hline & & &
\end{tabular}


Figure 3. Internal migration balances by district health board, 1986-1981 versus 1991-1996.

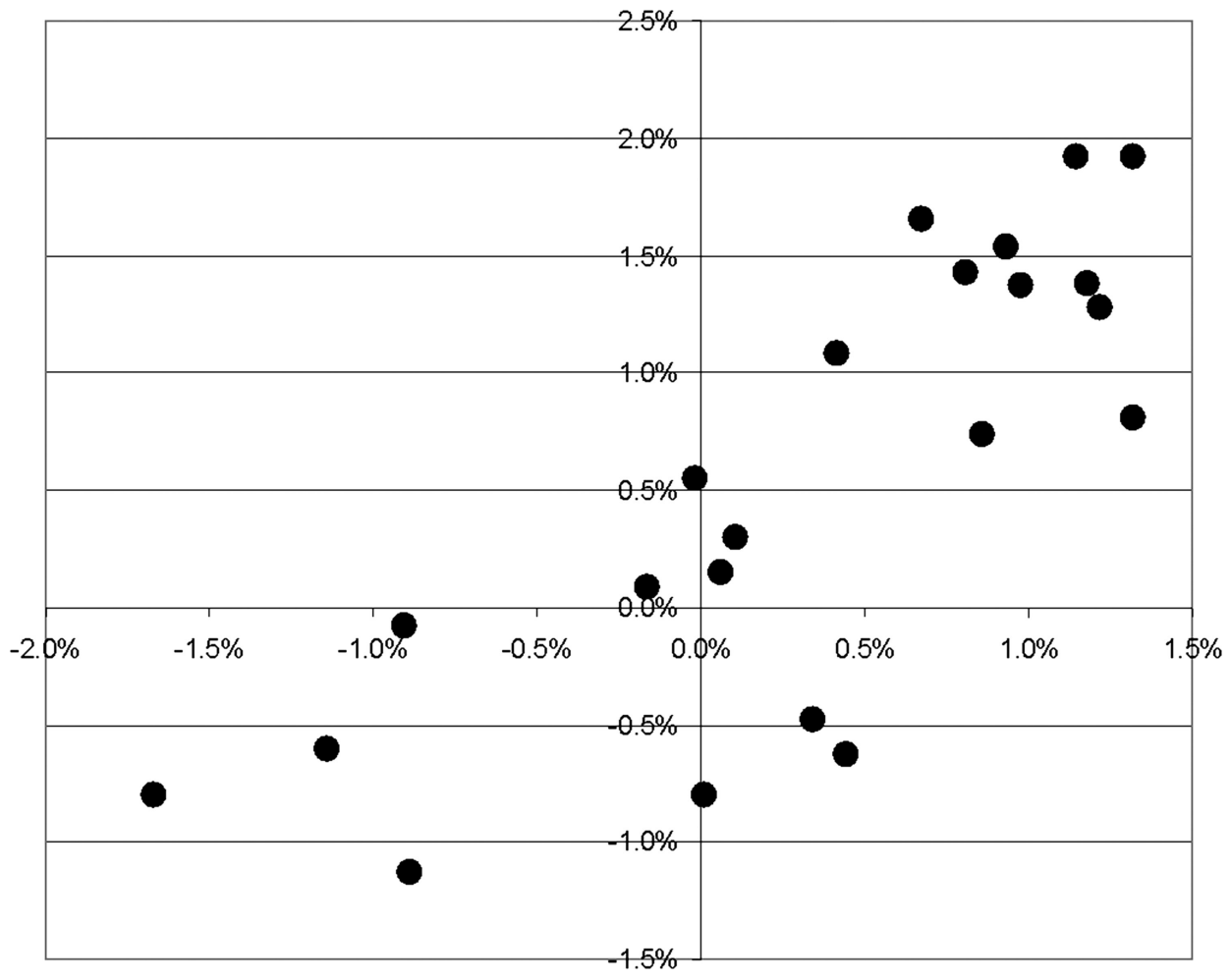

New Zealand than any region except for the Capital and Coast DHB (mainly the city of Wellington, 0.63 percent). In contrast, individuals who moved to the Otago DHB (containing the city of Dunedin) were slightly more likely to smoke than to have never smoked and so increase the smoking prevalence rates of that $\mathrm{DHB}$ by their arrival in net terms.

Table 4 shows the internal migration smoking balances for 1996 and 2006 as well as 1981 for males and females combined, but excluding immigrants. It can be noted that the spread of different experiences among DHBs increases over the study period (see the standard deviation at the end of the table, which rises over time). When males and females are included in the analysis, during the period from 1976 to 1981, Auckland gained smokers due to internal migration at a rate of 0.8 percent of the population every five years. The highest rate, however, was Tairawhiti (1.3 percent). The largest gains in 1996 and 2006 were in Waikato (1.9 and 2.1 percent, respectively). This accumulation of smokers in Waikato is consistent with the national-level pattern (Figures 3 and 4). The correlation coefficient between the smoking migration balances increased over the study period from $0.78(1981 / 1996)$ to 0.84 (1996/2006). These correlations suggest that the internal migration structure of smokers and nonsmokers in New Zealand is robust and we can therefore assume that these rates are representative of the period in general. These findings demonstrate the importance of differential migration effects on health inequalities, and how the consistency over time of this effect appears to have helped build up the geographical patterns now observed.

The analyses in Table 4 and Figures 3 and 4 do not include the effects of international in-migrants. The inclusion of immigrants from overseas exerts a strong effect on the results. The smoking-migration balance in many DHBs increased from values of typically around 1 percent of the total population migrating in five-year net, to values up to ten times this figure (Table 5). For example, with immigrants included, the smokingmigration balance in the Auckland DHB in 2006 was -10.9 percent compared to 0.8 percent with immigrants excluded. The addition of this group strengthened the overall relationship between the smoking-migration balances over the study period. The correlation coefficient increased from $0.81(1981 / 1996)$ to 0.97 (1996/2006). Figures 5 and 6 demonstrate the consistency of the net changes between the two sets of time periods.

\section{Smoking-Migration Balance and Life Expectancy}

To provide an indication of the effects of the selective migration patterns of smokers and nonsmokers 


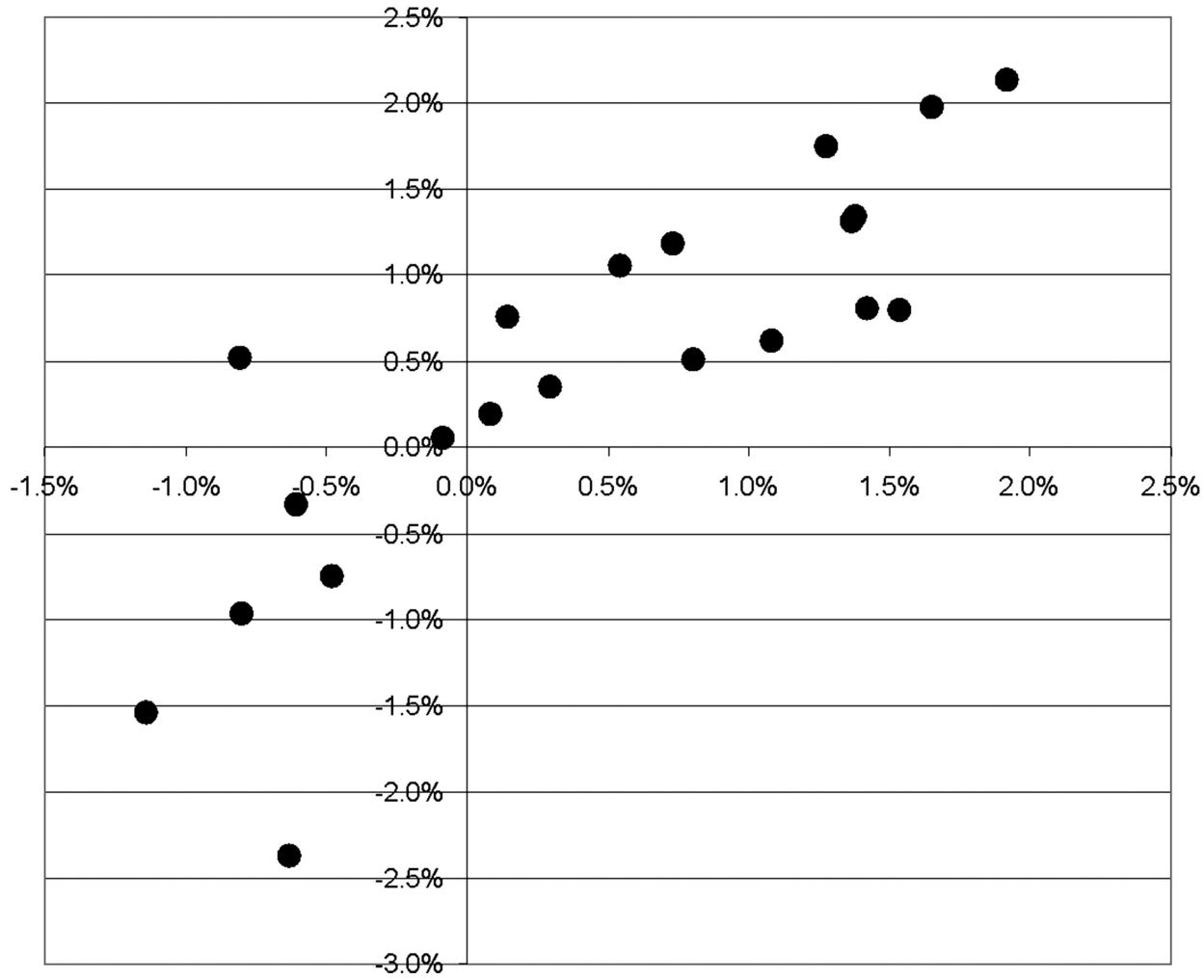

Figure 4. Internal migration balances by district health board, 1991-1996 versus 2001-2006.
Table 5. The smoking migration balance of men and women combined, including immigrants, by district health board: 1976-1981, 1991-1996, and 2001-2006, and standard deviation

\begin{tabular}{lrrr}
\hline District health board & 1981 & 1996 & 2006 \\
\hline Northland & $0.6 \%$ & $0.0 \%$ & $-1.5 \%$ \\
Waitemata & $-1.9 \%$ & $-5.5 \%$ & $-8.4 \%$ \\
Auckland & $-1.2 \%$ & $-8.5 \%$ & $-10.9 \%$ \\
Counties Manukau & $-1.8 \%$ & $-4.8 \%$ & $-7.6 \%$ \\
Waikato & $-0.3 \%$ & $-2.6 \%$ & $-3.7 \%$ \\
Lakes & $-0.1 \%$ & $-0.6 \%$ & $-1.5 \%$ \\
Bay of Plenty & $-2.0 \%$ & $-3.0 \%$ & $-4.2 \%$ \\
Tairawhiti & $1.0 \%$ & $0.4 \%$ & $0.0 \%$ \\
Taranaki & $0.3 \%$ & $0.0 \%$ & $-0.6 \%$ \\
Hawke's Bay & $0.3 \%$ & $-0.1 \%$ & $-1.9 \%$ \\
Whanganui & $1.1 \%$ & $0.0 \%$ & $0.0 \%$ \\
MidCentral & $-0.6 \%$ & $-3.0 \%$ & $-3.0 \%$ \\
Hutt Valley & $0.3 \%$ & $-0.4 \%$ & $-3.0 \%$ \\
Capital and Coast & $-2.2 \%$ & $-5.3 \%$ & $-8.2 \%$ \\
Wairarapa & $1.2 \%$ & $0.1 \%$ & $-1.9 \%$ \\
Nelson Marlborough & $-0.6 \%$ & $-2.3 \%$ & $-3.7 \%$ \\
West Coast & $1.2 \%$ & $1.3 \%$ & $0.6 \%$ \\
Canterbury & $-0.3 \%$ & $-3.9 \%$ & $-6.1 \%$ \\
South Canterbury & $0.9 \%$ & $-0.5 \%$ & $-1.4 \%$ \\
Otago & $0.0 \%$ & $-4.1 \%$ & $-6.6 \%$ \\
Southland & $0.7 \%$ & $-1.4 \%$ & $-1.7 \%$ \\
Standard deviation & 0.011 & 0.025 & 0.032 \\
\hline & & & \\
\hline
\end{tabular}

on the spatial pattern of health inequalities in New Zealand, the smoking-migration figures at the start of the period (1981) were compared to subsequent life expectancy (2001). There is a clear relationship between the DHB smoking-migration balance (described earlier) as a percentage of males in 1981, and life expectancy for males in 2001 (Figure 7). The more smokers that tend to leave each area compared to the net number of nonsmokers that arrive, the higher the DHBlevel life expectancy. Auckland is the white dot in Figure 7 , showing a balance of 1.2 percent as previously described. The overall differential in life expectancy for males between these areas in 2001 of around five years of life reflects well the net movements of smokers some twenty to twenty-five years earlier. The correlation between life expectancy in 2001 and net smoking migration balance in 1976 to 1981 is stronger for males $(-0.67)$ than for females $(-0.50)$, probably because compared to males, a lower proportion of females smoked (particularly in 1981).

\section{Discussion}

The results of this study demonstrate that over the past twenty-five years while smoking rates have fallen 
Figure 5. Internal migration balances augments by immigration by district health board, 1986-1981 versus 19911996.

Figure 6. Internal migration balances augmented by immigration by district health board, 1991-1996 versus 20012006.
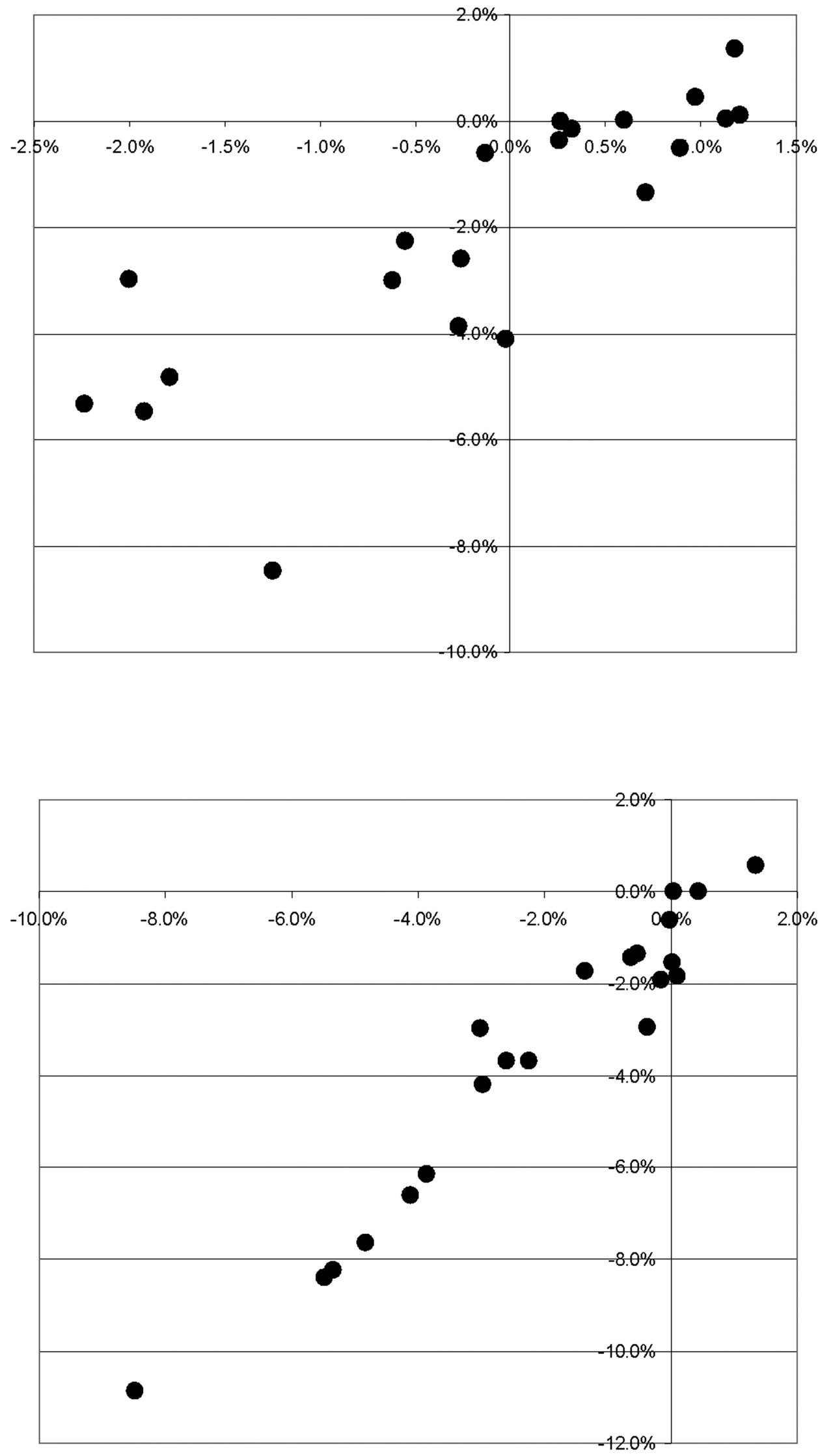


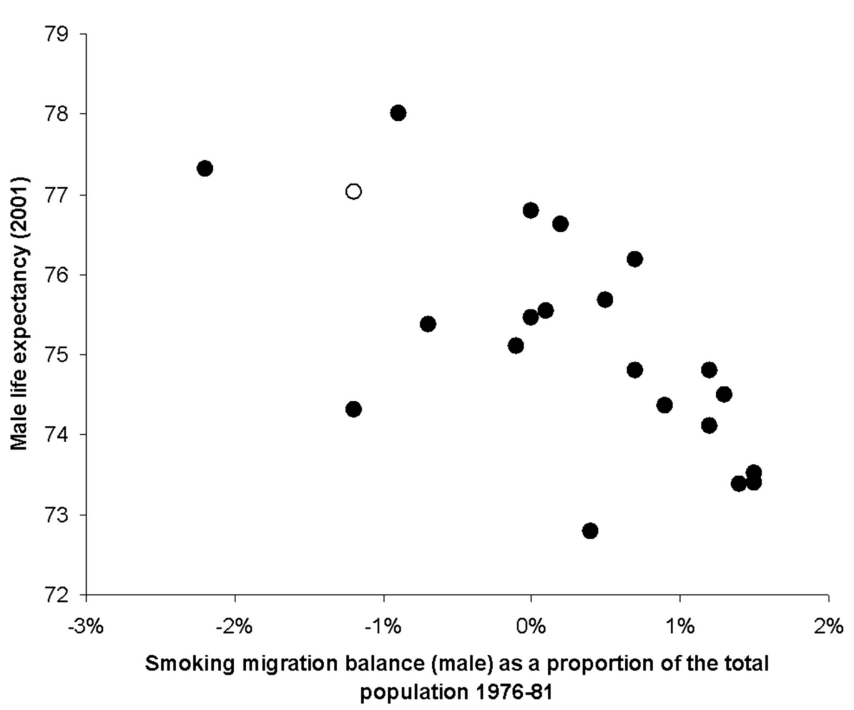

Figure 7. Life expectancy (in 2001) and migration of smokers and nonsmokers in New Zealand (1976-1981).

in all regions of New Zealand, the reduction in smoking prevalence has not been equal for all areas. Between 1981 and 2006, the reduction in smoking rates across the twenty-one DHBs ranged from approximately 25 percent (e.g., West Coast DHB) to around 50 percent (e.g., Capital and Coast DHB). Although the explanation for the spatial polarization in smoking rates between DHBs is likely to be multifaceted, one possible driver is the differential migration patterns between smokers and nonsmokers. We found evidence that the net balance of migration between smokers and nonsmokers varied substantially between the DHBs. Whereas some regions of New Zealand experienced a net increase in migrant smokers in each time period (e.g., Wairarapa and Whanganui), in other regions there was a persistent net increase in migrant nonsmokers (e.g., Auckland, and Capital and Coast). These trends remained consistent over time as DHBs with a net increase in smokers or nonsmokers between 1976 and 1981 tended to experience similar findings in later years. By excluding immigrants and considering the patterns attributable to internal migration relative to the overall changes, it is apparent that the arrival of significant numbers of immigrants more likely not to smoke in greater concentrations in some places than others has been very important to the smoking landscape in New Zealand.

Given the harmful effects of smoking on personal health, the selective movements of smokers and nonsmokers will clearly have played an important role in explaining the health gradient across regions of New Zealand. The smoking migration balance at the start of the study period (1976-1981) was strongly correlated with life expectancy twenty to twenty-five years later (2001), which suggests that the selective movement of smokers and nonsmokers might be an important mechanism underpinning spatial inequalities in health. For example, regions of New Zealand with a net increase in nonsmokers consistently had better health (i.e., higher life expectancy) than regions with a net gain in smokers. Further, the relationship between the migration balance and life expectancy was considerably stronger once immigrants were included in the analyses. These geographical stabilities in the differential patterns of migration reinforce the relationships shown here. Although causation cannot be inferred, it seems unlikely that life expectancy in 2001 is unrelated to the movement of smokers and nonsmokers twenty years earlier, especially as they are, as we have shown, representative of a long-term trend. These findings should not be overinterpreted to suggest that smoking alone is the key to explaining area health inequalities in New Zealand, but it is likely that nonsmokers move toward (healthier) areas where it is beneficial to live for a variety of reasons (employment and education opportunities, more attractive environment, etc.) and are more able to make such moves than are smokers. Smoking and nonsmoking are markers of socioeconomic position, reactions to adversity or comfort, and much more, as well as being direct influences on health themselves.

We have not made a direct estimate of the effect of selective migration patterns on the national health gradient because we do not have sufficient information on the smoking behavior of emigrants from New Zealand or on the extent to which smoking might be a proxy for other harmful effects on health and nonsmoking a proxy for other beneficial effects; however, the crude relationship suggested by Figure 7 is that a positive migration balance of approximately 1 percent net additional nonsmokers every five years for twentyfive years (1981-2006) results in about an extra year of life expectancy for the population as a whole; however, the direct effect of smoking contributes only around one third of this total (put crudely, five lots of 1 percent of seven years per smoker equals 0.35 years or about 4.2 months of extra life). It should be noted that areas attracting many nonsmokers are probably attracting migrants with many other advantages in life. It is plausible that areas to which more smokers than nonsmokers are moving are likely to have many features that are disadvantageous for health statistics other than simply the arrival of more smokers. Even if the migration of smokers "only" accounts for around one third of area 
differences in health this process of selective migration is likely to be one important explanation for the previously observed polarization of health outcomes between DHBs across New Zealand (Pearce and Dorling 2006; Pearce et al. 2006; Pearce, Tisch, and Barnett 2008).

The findings of this research concur with the international literature, which has tended to find significant selective migration effects on geographical variations in health. Research in the United Kingdom (Strachan, Leon, and Dodgeon 1995; Brimblecombe, Dorling, and Shaw 1999; Norman, Boyle, and Rees 2005; Connolly, O'Reilly, and Rosato 2007; Cox et al. 2007), the United States (Landale, Gorman, and Oropesa 2006), and Australia (Larson, Bell, and Young 2004) tends to suggest that the selective movement of "healthy" and "unhealthy" people strengthens the relationship between area measures of socioeconomic status and health. Of most relevance to this study, our findings are consistent with longitudinal research in Australia where after adjustment for socioeconomic and marital status, long-distance mobility among women was associated with being a smoker (Larson, Bell, and Young 2004). This work concerned migration within Australia and therefore the reported moves are analogous to those we report to specific areas of New Zealand.

Our results are perhaps unsurprising given the strong international evidence that migration streams are selective and that this process is an important explanation for the spatial health gradient observed in a number of countries, as well as the high levels of immigration into, and mobility within, New Zealand. The differential mobility patterns between smokers and nonsmokers are likely to reflect a complex set of social processes. Smokers in New Zealand are overrepresented in lower socioeconomic groups, more likely to live in more deprived areas, and more prone to having poorer health status. That the inclusion of international immigrants into the analyses markedly strengthened the relationship between smoking balance and life expectancy highlights the importance of considering the role of transnational migration in explaining geographical inequalities in health, especially in countries such as New Zealand with a large overseas-born population. Migrants into New Zealand tend to be healthier (and nonsmoking) than the rest of the population and do not distribute equally across all regions of the country. Instead, healthier migrants often arrive in the larger urban centers such as Auckland and Wellington, improving the overall health (or smoking status) of these regions. For example, smoking rates in Auckland fell from approximately 31 percent in 1981 to 19 percent in 1996 to 15 percent in 2006, and although smoking cessation among the local population will explain some of this reduction, the arrival of a larger proportion of nonsmoking immigrants (as well as to a lesser extent nonsmoking New Zealanders) is a key driver.

The selective movement of smokers is, to some degree, likely to reflect the higher levels of mobility among higher socioeconomic status (and healthier) individuals. Although frequent movements over short distances are strongly associated with socioeconomic disadvantage due to housing insecurity, interregional movements (such as those considered in this study) are more common among higher income groups, who are likely to be healthier and smoke less. Therefore, it is important to view the "decision" to smoke as partly a reflection of the social position in which people are situated. Previous New Zealand work on smoking has demonstrated the close link between social inequality and smoking (Barnett, Moon, and Kearns 2004; Barnett, Pearce, and Moon 2005). Similarly, Scottish research has demonstrated that living in a highly deprived and poorly resourced area provides an environment conducive to fostering smoking and discouraging cessation (Stead et al. 2001). Therefore, to elucidate the selective migration patterns of smokers and nonsmokers it is important to understand the complex and socially embedded explanations for the decision to smoke, as well as the intertwined factors that influence the extent to which people are mobile, and the distances they migrate. If these choices and experiences have, over the years, had more of an influence in some places than others, then the geographical processes and outcomes become self-reinforcing.

The findings of this study have important implications for researchers with interests in spatial inequalities in health. First, although many geographical studies in OECD nations have used a variety of health indicators to reveal that health has become more polarized over time, these studies have tended not to account for the important role of migration in explaining these trends. For example, studies in New Zealand have demonstrated that there has been a shift in the health gradient when areas are sorted by measures such as social deprivation (Pearce and Dorling 2006; Pearce et al. 2006; Pearce et al. 2007) or urban-rural status (New Zealand Ministry of Health 2007; Pearce, Barnett, and Jones 2007). This earlier work can be criticized for not evaluating the potential role of migration in confounding the altered relationship between area measures and local health status. Second, and related, our findings have 
repercussions for researchers seeking to evaluate various "contextual" determinants of health outcomes or behaviors, and health inequalities. The high levels of mobility and migration, as well as the selective nature of the movements in New Zealand, highlight the need to consider exposure to various place-based characteristics (e.g., local air pollution, neighborhood deprivation, and social capital) that individuals are exposed to at different temporal scales (e.g., over a day, the life course etc.). The vast majority of empirical research into "neighborhood effects" on health has been cross-sectional and has not grappled with the complex set of exposures that individuals face in residential and nonresidential settings leading to substantial potential for exposure underestimation, misclassification, or both (Inagami, Cohen, and Finch 2007). Similarly, the self-selection of people into areas as some people choose to move to particular neighborhoods, and the exclusion of those who cannot afford to move in, might confound some of the established associations between various features of places and the health status of local residents, a process known as endogeneity (Kawachi and Subramanian 2007). Any significant relationship between the characteristics of a place and a health outcome or health-related behavior might be an artifact of the selective movements of people and the subsequent clustering of people with similar health characteristics in the same area. As this study demonstrates, conceptual models of the causal pathways by which specific features of places influence health could usefully integrate a temporal dimension that utilizes detailed longitudinal data to evaluate the effect of contextual exposure over time. Such approaches are likely to be necessary if various area-based policy interventions designed to address these concerns are to be successfully implemented.

Finally, the findings have salience for research into health inequalities in other countries. If the patterns of migration and immigration have significant implications for health inequalities in New Zealand then it will no doubt matter greatly in other countries such as the United States and the United Kingdom. The United Kingdom has one of the highest rates of in- and outmigration of any large country in Europe (BBC News 2008). Area-level measurements of health status in London are especially affected by the population sorting that takes place when such large numbers of people come into and out of the city. Thus, the importance of immigration and emigration to selective migration patterns in $\mathrm{New}$ Zealand is likely to parallel processes elsewhere in the world where the direct smoking and migratory be- havior of the entire population is not monitored so effectively.

This study has limitations. First, we have examined the selective migration effects for only one spatial unit (DHBs across New Zealand). As previously noted, the spatial unit over which the migration flows are studied can be significant in determining whether selective migration is an important influence on geographical inequalities in health (Brimblecombe, Dorling, and Shaw 1999). If we had used smaller geographical units (e.g., territorial authorities; $n=73$ ), the total number of movements would have been greater, and it is possible that our use of relatively large spatial units might underestimate the full extent of the effects of selective migration on health inequalities in New Zealand. Second, we use a measure of health-related behavior (smoking) rather than a measure of health status per se. It is plausible that direct measures of mortality or morbidity might have detected different migration patterns. Nonetheless, smoking is a key intermediary linking socioeconomic status and health, and there are considerable opportunities for public health interventions that lessen the health burden of tobacco and reduce health inequalities. Finally, census information collected on smoking behavior does not allow us to ascertain smoking status at the time of a move or whether there was an alteration in smoking status at this time. It is therefore possible that our results could be influenced by a change in smoking status among the population of people who move within any of the five-year time periods. If people who move to a socially deprived area are more likely to take up smoking, and those who move in the opposite direction are more likely to give up smoking, those biases will confound our results. It is unlikely, however, that this issue is a significant concern because there is little evidence to suggest a link between a migration event and the initiation or cessation of smoking. Rather, a change in smoking behavior is more closely related to significant incidents over the life course such as a death in the family, divorce, change in employment status, and, most important, episodes of ill health.

\section{Conclusion}

This study has investigated the complex nature of migration streams to exemplify how geographical inequalities in health across regions of New Zealand are significantly influenced by the health (in this case smoking status) of the population entering and leaving each area. The results add to the international evidence that 
selective migration is an important process in explaining regional inequalities in health. It is important that future studies of spatial inequalities in health account for the potentially important effect of selective mobility that might otherwise lead to interpretations of ecological associations and area effects that are, in fact, artifactual. Accounting for the selective mobilities of people with varying health outcomes, needs, and experiences is an important domain for future research endeavor. Augmenting the understanding of health and mobility provides a considerable opportunity to enhance the appreciation of geographical processes in explaining and addressing inequalities in health.

\section{Acknowledgments}

The authors thank Ewan Jonasen from Statistics New Zealand for extracting the census records. Thanks also to Paul Bealing for creating the map, and to John Pritchard for producing the diagram. The comments from the three anonymous reviewers were extremely useful. Jamie Pearce was a member of staff at the Department of Geography, University of Canterbury, New Zealand, when the analyses were undertaken.

\section{References}

Anderson, D. O., B. G. Ferris, Jr., and R. Zickmantel. 1964. Levels of air pollution and respiratory disease in Berlin, New Hampshire. American Review of Respiratory Disease 90:877-87.

Barnett, J. R. 2000. Does place of residence matter? Contextual effects and smoking in Christchurch. New Zealand Medical Journal 113 (1120): 433-35.

Barnett, R., G. Moon, and R. Kearns. 2004. Social inequality and ethnic differences in smoking in New Zealand. Social Science and Medicine 59 (1): 129-43.

Barnett, R., J. Pearce, and G. Moon. 2005. Does social inequality matter? Changing ethnic socio-economic disparities and Maori smoking in New Zealand, 1981-1996. Social Science and Medicine 60 (7): 151526.

BBC News. 2008. Brits abroad 2008. http://news.bbc.co.uk/1/ shared/spl/hi/in_depth/brits_abroad/html/default.stm (last accessed 4 June 2008).

Bedford, R. 2004. The quiet revolution: Transformations in migration policies, flows and outcomes, 1999-2004. New Zealand Geographer 60 (2): 58-62.

Bentham, G. 1988. Migration and morbidity: Implications for geographical studies of disease. Social Science and Medicine 26 (1): 49-54.

Blakely, T., and N. Wilson. 2005. The contribution of smoking to inequalities in mortality by education varies over time and by sex: Two national cohort studies, 1981-84 and 1996-99. International Journal of Epidemiology 34 (5): 1054-62.

Brimblecombe, N., D. Dorling, and M. Shaw. 1999. Mortality and migration in Britain: First results from the British Household Panel Survey. Social Science and Medicine 49 (7): 981-88.

Connell, J. 2007. At the end of the world: Holding on to health workers in Niue. Asian and Pacific Migration Journal 16 (2): 179-97.

Connolly, S., and D. O'Reilly. 2007. The contribution of migration to changes in the distribution of health over time: Five-year follow-up study in Northern Ireland. Social Science and Medicine 65 (5): 1004-11.

Connolly, S., D. O’Reilly, and M. Rosato. 2007. Increasing inequalities in health: Is it an artefact caused by the selective movement of people? Social Science and Medicine 64 (10): 2008-15.

Cox, M., P. J. Boyle, P. Davey, and A. Morris. 2007. Does health-selective migration following diagnosis strengthen the relationship between Type 2 diabetes and deprivation? Social Science and Medicine 65 (1): 32-42.

Dalgard, O. S., and K. Tambs. 1997. Urban environment and mental health: A longitudinal study. British Journal of Psychiatry 171:530-36.

Davey Smith, G., D. Dorling, R. Mitchell, and M. Shaw. 2002. Health inequalities in Britain: Continuing increases up to the end of the 20th century. Journal of Epidemiology and Community Health 56 (6): 434-35.

Dorling, D. 2006. Commentary: The fading of the dream: Widening inequalities in life expectancy in America. International Journal of Epidemiology 35 (4): 979-80.

Dorling, D., and B. Thomas. 2004. People and places: A 2001 census atlas of the UK. Bristol, UK: Policy Press.

Fox, A., and P. Goldblatt. 1982. Longitudinal study: Sociodemographic mortality differentials. London: HMSO.

Inagami, S., D. A. Cohen, and B. K. Finch. 2007. Non-residential neighborhood exposures suppress neighborhood effects on self-rated health. Social Science and Medicine 65 (8): 1779-91.

Kawachi, I., and S. V. Subramanian. 2007. Neighbourhood influences on health. Journal of Epidemiology and Community Health 61 (1): 3-4.

Kelsey, J. L., E. W. Mood, and R. M. Acheson. 1968. Population mobility and epidemiology of chronic bronchitis in Connecticut. Archives of Environmental Health 16 (6): 853-61.

Landale, N. S., B. K. Gorman, and R. S. Oropesa. 2006. Selective migration and infant mortality among Puerto Ricans. Maternal and Child Health Journal 10 (4): 35160.

Larson, A., M. Bell, and A. F. Young. 2004. Clarifying the relationships between health and residential mobility. Social Science and Medicine 59 (10): 2149-60.

Le Heron, R. B., and E. Pawson. 1996. Changing places: New Zealand in the nineties. Auckland, New Zealand: Longman Paul.

Moon, G., and J. R. Barnett. 2003. Spatial scale and the geography of tobacco smoking in New Zealand: A multilevel perspective. New Zealand Geographer 59 (2): 6-15.

New Zealand Department of Labour. 2003. Migrants in New Zealand: An analysis of 2001 census data. Wellington, New Zealand: Department of Labour. 
New Zealand Ministry of Health. 2003. Tobacco facts 2003. Wellington, New Zealand: Ministry of Health. . 2005. Frequently asked questions about District Health Boards. Wellington, New Zealand: Ministry of Health. - 2007. Urban-rural health comparisons: Key results of the 2002/03 New Zealand Health Survey. Wellington, New Zealand: Ministry of Health.

Norman, P., P. Boyle, and P. Rees. 2005. Selective migration, health and deprivation: A longitudinal analysis. Social Science and Medicine 60 (12): 2755-71.

North, N. 2007. International nurse migration: Impacts on New Zealand. Policy, Politics, and Nursing Practice 8 (3): 220-28.

Organisation for Economic Cooperation and Development (OECD). 2008. OECD factbook 2008: Economic, environmental, and social statistics. Paris: OECD.

Pearce, J., R. Barnett, S. Collings, and I. Jones. 2007. Did geographical inequalities in suicide among men aged 15-44 in New Zealand increase during the period 19802001? Australia and Zealand Journal of Psychiatry 41 (4): $359-65$.

Pearce, J., R. Barnett, and I. Jones. 2007. Have urban/rural inequalities in suicide in New Zealand grown during the period 1980-2001? Social Science and Medicine 65 (8): $1807-19$.

Pearce, J., and D. Dorling. 2006. Increasing geographical inequalities in health in New Zealand, 1980-2001. International Journal of Epidemiology 35 (3): 597603.

Pearce, J., D. Dorling, B. Wheeler, R. Barnett, and J. Rigby. 2006. Geographical inequalities in health in New Zealand, 1980-2001: The gap widens. Australian and New Zealand Journal of Public Health 30 (5): 461-66.

Pearce, J., R. Hiscock, G. Moon, and R. Barnett. 2009. The neighbourhood effects of geographical access to tobacco retailers on individual smoking behaviour. Journal of Epidemiology and Community Health 63 (1): 6977.

Pearce, J., C. Tisch, and R. Barnett. 2008. Have geographical inequalities in cause-specific mortality in New Zealand increased during the period 1980-2001? New Zealand Medical Journal 121 (1281): 15-27.

Shaw, M., R. Mitchell, and D. Dorling. 2000. Time for a smoke? One cigarette reduces your life by 11 minutes. British Medical Journal 320 (7226): 53.
Singh, G. K., and M. Siahpush. 2006. Widening socioeconomic inequalities in US life expectancy, 1980-2000. International Journal of Epidemiology 35 (4): 969-79.

Smith, S. J., and D. Easterlow. 2005. The strange geography of health inequalities. Transactions of the Institute of British Geographers 30 (2): 173-90.

Spoonley, P., and R. Bedford. 2008. Responding to regional labour demand: International migration and labour markets in New Zealand's regions. Journal of International Migration and Integration 9 (2): 203-23.

Statistics New Zealand. 2007a. QuickStats about culture and identity. Wellington: Statistics New Zealand.

- 2007b. QuickStats about population mobility. Wellington: Statistics New Zealand.

. 2007c. QuickStats national highlights. Wellington: Statistics New Zealand.

. 2007d. Survey of dynamics and motivation for migration in New Zealand: March 2007 quarter. Wellington: Statistics New Zealand.

Stead, M., S. MacAskill, A. M. MacKintosh, J. Reece, and D. Eadie. 2001. "It's as if you're locked in": Qualitative explanations for area effects on smoking in disadvantaged communities. Health and Place 7 (4): 333-43.

Strachan, D. P., D. A. Leon, and B. Dodgeon. 1995. Mortality from cardiovascular disease among interregional migrants in England and Wales. British Medical Journal 310 (6977): 423-27.

U.S. Office of the Surgeon General. 2004. 2004 Surgeon General's report: The health consequences of smoking. Atlanta, GA: U.S. Department of Health and Human Services, Centers for Disease Control and Prevention, National Center for Chronic Disease Prevention and Health Promotion, Office on Smoking and Health.

van Lenthe, F. J., P. Martikainen, and J. P. Mackenbach. 2007. Neighbourhood inequalities in health and healthrelated behaviour: Results of selective migration? Health and Place 13 (1): 123-37.

Verheij, R. A., H. D. van de Mheen, D. H. de Bakker, P. P. Groenewegen, and J. P. Mackenbach. 1998. Urbanrural variations in health in The Netherlands: Does selective migration play a part? Journal of Epidemiology and Community Health 52 (8): 487-93.

Worldmapper. 2008. Worldmapper: The world as you've never seen it before. http://www.worldmapper.org/ (last accessed 4 June 2008).

Correspondence: Institute of Geography, School of GeoSciences, University of Edinburgh, Drummond St, Edinburgh EH8 9XP, United Kingdom, e-mail: jamie.pearce@ed.ac.uk (Pearce); Department of Geography, University of Sheffield, Sheffield, S10 2TN, United Kingdom, e-mail: daniel.dorling@sheffield.ac.uk (Dorling). 